\title{
HELENA ANTIPOFF E A EDUCAÇÃO DOS "EXCEPCIONAIS": UMA ANÁLISE DO TRABALHO COMO PRINCÍPIO EDUCATIVO ${ }^{1}$
}

\author{
Heulalia Charalo Rafante ${ }^{2}$ \\ heulaliarafante@yahoo.com.br \\ Roseli Esquerdo Lopes ${ }^{3}$ \\ Universidade Federal de São Carlos - UFSCar \\ relopes@ufscar.br
}

\section{RESUMO:}

Trata-se de uma pesquisa histórica, baseada em fontes documentais, cuja análise acompanhou os primeiros anos da trajetória da educadora russa Helena Antipoff no Brasil, focando suas atividades no sistema de ensino mineiro, especialmente, nas instituições criadas por ela para atender a crianças consideradas "excepcionais": a Sociedade Pestalozzi (1932), o Pavilhão de Natal (1934), o Instituto Pestalozzi (1935) e a Fazenda do Rosário (1940). Investigamos os mecanismos de seleção daqueles atendidos nessas instituições e caracterizamos o perfil e a trajetória dos internos; analisamos os princípios educativos colocados em práticas nessas instituições. Partimos do conceito de institucionalização, entendido como um instrumento dos setores dominantes da sociedade para conservar a ordem vigente, no sentido de detectar o diferente e isolá-lo, numa estrutura de organização social que produz a contradição. Uma vez institucionalizados, a formação dos internos visava prepará-los para o trabalho e este era o fio condutor das atividades, substituindo os estudos e as brincadeiras. Essa educação visava à produção da adaptação dos internos a uma realidade social pré-estabelecia, sendo, portanto, a educação 'apenas' um meio para, de fato, proteger e conservar o ordenamento social.

Palavras-chave: História da Educação; Educação e Trabalho; Educação Especial; Educação e Pessoas com Deficiência; Helena Antipoff.

\section{HELENA ANTIPOFF AND EDUCATION OF THE "EXCEPTIONAL" ONES: AN ANALYSIS OF THE WORK AS EDUCATIONAL PRINCIPLE}

\begin{abstract}
:
This article is about a historical research, based on documental sources, that follows the initial years of the Russian educator Helena Antipoff in Brazil, focusing on her activities in the educational system of the State of Minas Gerais, specially on the institutions that she built to attend children that were considered "exceptional": the Sociedade Pestalozzi (1932), the Pavilhão de Natal (1934), the Instituto Pestalozzi (1935) and the Fazenda do Rosário (1940). It was investigated the selection mechanism of those children, characterized their profile and their history's lives and finally analyzed the educational principle implemented in those institutions. It was used the concept of institutionalization understood as an instrument of dominant sections of society to conserve the current order, with the purpose to detect the different and isolate it, in a structure of social organization that produces contradiction. Once institutionalized, the formation of the children had for objective making them able for the labor market and the conducting wire of the activities was the work itself that replaced the studies and the play. This education aimed at to the production of the adaptation of the internees to an already-shaped social reality, being, therefore, the education only a path, indeed, to protect and conserve the social order.

Keywords: History of Education; Education and Work; Special Education; Education and People with Disabilities; Helena Antipoff.
\end{abstract}




\section{Introdução}

Este artigo apresenta uma pesquisa histórica, baseada em fontes documentais, cuja análise buscou fazer emergir a trajetória da educadora russa Helena Antipoff (1892-1974) e sua atuação no ensino da capital mineira, nas décadas de 1930 e 1940, principalmente, as instituições propostas por ela para atender a crianças "excepcionais" : o Pavilhão de Natal $(1934)^{5}$, o Instituto Pestalozzi (1935) e a Fazenda do Rosário (1940).

Helena Antipoff nasceu na Rússia em 1892 e, em 1908, mudou-se para França. No Laboratório de Psicologia da Universidade de Paris, participou da padronização dos testes de nível mental de crianças, elaborada por Alfred Binet e Théodule Simon. Nesse período, conheceu Edouard Claparède, que a convidou para fazer parte do Instituto Jean-Jacques Rousseau, na Suíça, onde concluiu o curso de Psicologia, com especialização em Psicologia da Educação. Sua experiência profissional teve início na Maison Des Petits, escola anexa ao Instituto Jean-Jacques Rousseau. Os princípios da "Escola Sob Medida"6, o método de "Experimentação Natural"7 e os testes de inteligência, elaborados por Alfred Binet e Théodule Simon, fundamentaram sua prática pedagógica. Retornando à Rússia, em 1916, trabalhou com crianças órfãs, vítimas da Primeira Guerra e da Revolução Russa.

De volta à Genebra, em 1925, atuou como assistente de Claparède, no Laboratório de Psicologia, até ser convidada pelo governo de Minas Gerais para auxiliar na implantação da Reforma de Ensino, empreendida naquele Estado, a partir de 1927. Ao chegar ao Brasil, em 1929, Helena Antipoff assumiu o cargo de professora de Psicologia, na Escola de Aperfeiçoamento, onde organizou o Laboratório de Psicologia, ministrou aulas, realizou pesquisas junto aos alunos do ensino primário dos grupos escolares de Belo Horizonte e, ainda, auxiliou no processo de homogeneização das classes escolares.

Com base nas atividades junto aos grupos escolares, no início da década de 1930, Helena Antipoff fez um diagnóstico do sistema de ensino mineiro (ANTIPOFF, 1992f, 1992g, 1992h), destacando três problemas: 1) não ocorria, nas escolas, a orientação profissional das crianças; 2) a formação física, moral e intelectual das crianças, ao saírem da escola primária, apresentava-se incompleta; 3) havia crianças que se encontravam "em perigo moral" 8 . Para a educadora, essas questões estariam relacionadas à duração da escolaridade que, se comparada a outros países, era menor. O problema da criança "em perigo moral", principalmente, seria resultado do próprio sistema de ensino e, fazendo uma crítica à pedagogia tradicional, conclamou a pedagogia experimental.

Para Helena Antipoff, a escola não atendia às necessidades das crianças, justamente por não incorporar os princípios científicos preconizados pela pedagogia experimental. Assim, a educadora direcionou sua atuação no sentido de criar instituições para receber essas crianças consideradas "excepcionais", , retirando-as do sistema de ensino oficial, sob a justificativa de que a escola era responsável pela não adaptação dessas crianças.

Em 1932, a educadora criou a Sociedade Pestalozzi, associação civil que centralizou as ações direcionadas aos "excepcionais" em Belo Horizonte, buscando viabilizar outras instituições educacionais, a saber: o Pavilhão de Natal (1934), o Instituto Pestalozzi (1935) e a Fazenda do Rosário (1940). Este artigo, além da trajetória de Helena Antipoff, apresenta as atividades propostas para as instituições, a fim de compreender os princípios educativos colocados em prática nesses estabelecimentos.

Para essa análise, partimos da categoria institucionalização, formulada por Franco e Franca Basaglia (1977) que, considerando a divisão de classes engendrada pelo modo de produção capitalista, destacam que a aceitação dessa divisão como fenômeno natural exige regras e instituições que, aparentemente destinadas a resolver as contradições, servem para manter a divisão original sob a qual se ergue o sistema capitalista. $\mathrm{O}$ processo de institucionalização é um instrumento dos setores dominantes da sociedade para conservar a ordem vigente, no sentido de detectar o diferente e isolá-lo, buscando esconder o fato de 
que é a estrutura da organização social que produz a diferença, sendo que os diferentes são aqueles indivíduos que não produzem e que, voluntária ou involuntariamente, são excluídos da sociedade. A estratégia é estabelecer o diferente a priori, possibilitando aplicar a definição mais adequada para justificar uma intervenção repressiva, sendo que os mecanismos de intervenção ou instituições de violência são os presídios, manicômios, institutos terapêuticos, de controle, de reabilitação e de segregação em que, por meio da mistificação da terapia e da reabilitação, obtém-se a conservação da ordem pública, o ritmo produtivo e a eficiência da organização social (BASAGLIA \& BASAGLIA, 1977).

Considerando esses pressupostos, levantamos a questão de pesquisa: as ações empreendidas por Helena Antipoff atenderam às necessidades dos "excepcionais" institucionalizados ou constituíram-se enquanto resposta ao meio social?

Esse referencial aponta dois caminhos para o técnico que atua no processo de institucionalização: - ser o encarregado de controlar a contenção, justificada pelas ideologias científicas, de forma que a segregação não é resposta para o segregado e sim para a sociedade que criou a instituição; - ou, em contraposição, por intermédio de sua prática, tomar consciência dos mecanismos que fundamentam as instituições e passar a atuar no sentido de que o objeto da manipulação se aproprie dos conhecimentos que justificam seu estado de segregado ao ponto de recusá-los. As teorizações dos Basaglia destacam a discussão acerca do "trabalho técnico + político" como categoria que dimensiona a atuação daqueles especialistas em instituições de violência e apresenta uma possibilidade de ação visando à transformação social ou, inversamente, à sua manutenção. A partir de Gramsci, essa categoria evidencia a função também política que o técnico assume na sociedade, articulando a especificidade particular da ação técnica à estrutura social da qual a instituição faz parte, descobrindo suas conexões e implicações, pois "es necesario unirse a un análisis de la estructura social, saliendo de la separación especializada la cual son prisioneras cada institución y cada técnico que trabaja en ellas" (BASAGLIA \& BASAGLIA, 1977, p. 90). Sem estabelecer essa relação, os técnicos assumem a posição de funcionários do consenso, de serem "os 'comissários' do grupo dominante para os exercícios das funções subalternas de hegemonia social e governo político" (GRAMSCI, 1978, p. 11). Diante desses apontamentos, buscamos compreender qual o caminho seguido pela atuação de Helena Antipoff junto aos "excepcionais" das instituições em análise neste texto.

Para a realização dessa pesquisa, a riqueza documental preservada na Fundação Helena Antipoff, em Ibirité, onde se iniciaram as atividades da Fazenda do Rosário, e no Centro de Documentação e Pesquisa Helena Antipoff, na Biblioteca Central da Universidade Federal de Minas Gerais, foram fundamentais. Constituíram fontes para nosso estudo os artigos escritos por Helena Antipoff, apresentando resultados de pesquisas, bem como os textos referentes às palestras, às conferências, aos seminários proferidos por ela. Destacamos que a educadora não escreveu nenhum livro, pois, segundo seu filho, Daniel Antipoff (1975), ela preferiu agir e ensinar pelas ações, a partir do seu próprio exemplo. Essa característica do material nos levou a uma garimpagem, facilitada pelo fato de que grande parte dos textos encontra-se reunida em cinco volumes, organizados pelo Centro de Documentação e Pesquisa Helena Antipoff. Outras fontes importantes foram os diários escritos pelas professoras da Fazenda do Rosário, que registraram os acontecimentos desde o início de suas atividades, em 1940. Todavia, não localizamos todos os diários da década de 1940. Trabalhamos com um documento inédito, intitulado "A Fazenda do Rosário Através dos Registros", em que Helena Antipoff fez um recorte dos diários das professoras e organizou o texto, apresentando passagens do cotidiano da Fazenda. Consultamos também a biografia de Helena Antipoff, escrita por Daniel Antipoff e publicada em 1975, e artigos publicados pelas professoras que trabalharam na Fazenda 
do Rosário ou foram alunas dos cursos de treinamento para professores rurais, oferecidos pela instituição, a partir de 1948.

\section{Helena Antipoff e o Ensino Primário na capital mineira, na década de 1930}

Ao chegar ao Brasil em 1929, Helena Antipoff assumiu o cargo de professora de Psicologia da Escola de Aperfeiçoamento ${ }^{10}$, onde organizou o Laboratório de Psicologia e realizou pesquisas junto aos alunos do ensino primário dos grupos escolares de Belo Horizonte e, ainda, auxiliou no processo de homogeneização das classes desses grupos escolares.

O curso na Escola de Aperfeiçoamento, com duração de dois anos, funcionava em período integral e as aulas conjugavam a parte teórica com as atividades práticas, referentes a pesquisas realizadas nas escolas públicas, cujo objetivo era conhecer "a conduta da criança, seus modos diferentes de reagir durante o trabalho escolar, ou mesmo durante o recreio" (ANTIPOFF, 1992c, p. 59). Era o Método de Experimentação Natural aplicado à realidade brasileira e, com o intuito de subsidiar a implantação das classes homogêneas, previstas na Reforma de Ensino (1927), os testes de inteligência geral, inspirados na escala métrica Binet-Simon, também foram aplicados. Por fim, para verificar os ideais e os interesses das crianças mineiras, foi utilizado o método de inquérito, que "cumpre deixar a criança exprimir-se livremente a fim de lhe conhecer a mentalidade, a estrutura psicológica" (ANTIPOFF, 1992b, p. 63). O conhecimento da criança era, para Helena Antipoff, algo complexo e nenhum método deveria ser utilizado isoladamente. A educadora sugeriu a aplicação de vários testes e a contraposição dos resultados com a observação direta da criança, pois "onde a observação coincide com o teste, o diagnóstico é mais seguro" (ANTIPOFF, 1992d, p. 128). Essas investigações, além de subsidiar a implantação das classes homogêneas, visavam iniciar as alunas no método da psicologia experimental, orientar Helena Antipoff quanto ao perfil das crianças mineiras, com o intuito de fornecer parâmetros para avaliação anual dos alunos e, em última instância, aplicar os princípios da Escola Ativa, apresentados nos termos da Reforma de Ensino.

Os resultados dessas pesquisas levaram Helena Antipoff a fazer um diagnóstico do sistema de ensino mineiro, destacando três problemas: 1) a orientação profissional da criança não ocorria nas escolas; 2) a formação física, moral e intelectual incompleta das crianças ao saírem da escola primária; 3) o problema das crianças "em perigo moral". Quanto ao último problema, a educadora destacou que tal questão emergiu durante suas atividades relacionadas à organização das classes homogêneas nas escolas públicas de Belo Horizonte e, de acordo com ela, as crianças indisciplinadas, desequilibradas, que apresentavam perturbações de caráter e anti-sociais, não constituíam exceções nos grupos escolares: "vimos bom número de fichas psicológicas dessas crianças, como tivemos pessoalmente trato com elas" (ANTIPOFF, 1992h, p. 57). Para a educadora, esses problemas estariam relacionados à duração da escolaridade que, se comparada com países da América do Norte e da Europa, era menor (ANTIPOFF, 1992g), portanto, seriam resultado do próprio sistema de ensino e, fazendo uma crítica à pedagogia tradicional, conclamou a pedagogia experimental, baseada na experimentação contínua, na busca de meios adequados para ajudar a criança a viver em harmonia consigo mesma e com a sociedade na qual estava inserida:

Jamais a educação se tornará a cura que dela espera a sociedade e os governos para diminuir, num futuro mais ou menos próximo, o rebotalho humano miserável, que enche os hospitais, os manicômios, as prisões, se ela não abandonar o mais depressa possível seu diletantismo superficial e não se transformar numa arte precisa aplicada ao melhoramento da raça 
humana e munida dos meios que lhe forja a ciência, que nunca se cansa de as aperfeiçoar (ANTIPOFF, 19921, p. 49).

As colocações de Helena Antipoff, a partir de suas pesquisas sobre o sistema de ensino mineiro e a investigação a respeito da Reforma de Ensino em Minas Gerais (PEIXOTO, 1981), evidenciaram que os novos métodos de ensino propostos pela Reforma Francisco Campos não se efetivaram nas escolas mineiras como um todo. Para a educadora, a permanência dos métodos antigos, considerados por ela inadequados, juntamente com a pouca duração da escolaridade obrigatória, eram os responsáveis pelo problema da criança "em perigo moral".

Essas aberrações podem residir na natureza tarada e viciada da criança; podem igualmente provir dos métodos insuficientes ou falsos de educação que não levam em consideração a personalidade da criança, que não sabem organizar o regime de vida e o trabalho pedagógico de acordo com as necessidades da criança, com a sua idade e seu tipo individual (ANTIPOFF, 19921, p. 130).

\section{Do diagnóstico do Ensino Mineiro às instituições para os "Excepcionais"}

Em sua atuação junto ao sistema de ensino mineiro, Helena Antipoff concluiu que a escola não atendia às necessidades das crianças, justamente por não incorporar os princípios científicos preconizados pela pedagogia experimental. No entanto, a educadora não considerou as contradições humanas como um produto histórico-social.

Seja filho de um ricaço ou de um proletário, indiferentemente, se apresenta um grau de desenvolvimento mais baixo ou mais alto do que a média do meio, será localizado em tal ou outro tipo de classe escolar, não segundo sua condição social, mas, pelo contrário, segundo seu valor individual. Uma certa porção de crianças do grupo social privilegiado se encontra nas classes fracas, como um bom número de crianças da categoria mais modesta nas classes fortes (ANTIPOFF, 1992k, p. 44).

Aparentemente, Helena Antipoff não vislumbrou o significado político de suas ações, visto que, segundo Franca e Franco Basaglia (1977), isso implicaria, além do reconhecimento dos limites da ciência, a percepção da classe a qual pertenciam os usuários das instituições: "proletarios o subproletarios, son de la misma clase todos os usuarios de instituciones reeducativas y asistenciales" (BASAGLIA \& BASAGLIA, 1977, p. 92). Os testes utilizados para separar as crianças em classes homogêneas obedeciam "(...) menos à diferença do desenvolvimento mental sui generis e a dispersão das disposições inatas, do que a variação do grau de civilização que caracteriza cada grupo social (...)" (ANTIPOFF, 1992k, p. 44), quer dizer, os testes mediam a inteligência moldada pelo meio social em que vivia a criança, havendo uma correlação entre o meio sócio-econômico e o desenvolvimento mental. Considerando essa característica dos testes, Helena Antipoff observou que crianças muito inteligentes no meio operário eram raras.

(...) crianças muito inteligentes no meio operário são raras e por isso merecem dos pedagogos maior atenção, porque essa inteligência espontânea as quais o meio não favoreceu poderão, graças à escola, atingir um desenvolvimento extraordinário e contribuir, no futuro, para a prosperidade do país (ANTIPOFF, 1992d, p. 123). 
Para aquelas crianças que não possuíam essa inteligência espontânea, a educadora sugeriu às escolas a prática da "ortopedia mental", um conjunto de exercícios criados por Alfred Binet, em 1910, que, partindo da arte de corrigir as deformidades do corpo, pretendia endireitar, adestrar e fortificar as faculdades mentais. Acreditava-se que, treinando as funções mentais, submetendo-as a exercícios repetidos e metódicos, seria possível melhorá-las (ANTIPOFF, 1992i). Dessa forma, para minimizar as conseqüências das diferenças sociais, sugeriu uma educação compensatória (ANTIPOFF, 1992j). Mesmo constatando que as crianças de meio social privilegiado se sobressaíam nos testes psicológicos, Antipoff não questionou a aplicação dos mesmos, afirmando que continuaria "a preconizar a seleção de crianças segundo os testes, chamados de inteligência" (ANTIPOFF, 1992k, p. 44). Tomando como pressuposto que "essas diferenças intelectuais dependentes do meio tendem mais e mais a nivelar-se no decurso dos anos escolares" (ANTIPOFF, 1992k, p. 44), justificou a continuidade dessa prática. Além disso, o contato entre as crianças de classes sociais diferentes não ocorreria de forma repentina, o que, segundo Antipoff, "poderia provocar uma desadaptação por demais intensa" (ANTIPOFF, 1992k, p. 45).

A partir dessas constatações relacionadas aos testes de inteligência, inferimos que o futuro da criança estava condicionado pelo meio social a que pertencia. Reforça essa evidência o atendimento feito por Helena Antipoff a oito crianças que procuraram o Instituto Pestalozzi, em 1935, para serem examinadas, já que foram consideradas possuidoras de uma inteligência acima do que era considerado normal. A seguir, o diagnóstico:

\begin{abstract}
Umas realmente foram brilhantes, outras apenas normais, ligeiramente acima da média e ainda insuficientes os seus quocientes intelectuais para cursar com êxito a escola secundária. Como se tratava de adolescentes de meio humilde, desaconselhamos aos pais pleitear a admissão nos ginásios, pois não apresentavam aptidões necessárias para vencer as provas e entrar nas carreiras liberais (ANTIPOFF, 1992n, p. 192).
\end{abstract}

Esse mesmo tipo de avaliação foi feito com as crianças das escolas primárias do sistema de ensino mineiro, das quais foram destacadas por Helena Antipoff as crianças "indisciplinadas", "desequilibradas", "com perturbações de caráter", "anti-sociais", enfim, as "particularmente difíceis de educar". Levando em conta que o meio social influenciava positiva ou negativamente nos testes, podemos afirmar que as crianças com necessidade de uma educação especial eram provenientes das classes mais pobres da capital mineira. A educadora direcionou sua atuação no sentido de criar instituições para receber essas crianças consideradas "excepcionais", retirando-as do sistema de ensino oficial, sob a justificativa de que a escola era responsável pela não adaptação dessas crianças. $\mathrm{O}$ primeiro passo de Helena Antippoff em direção à assistência aos "excepcionais" foi a criação da Sociedade Pestalozzi, em 1932, e que buscou viabilizar outras instituições para atender a crianças "excepcionais": o Pavilhão de Natal, o Instituto Pestalozzi e a Fazenda do Rosário.

\title{
A Sociedade Pestalozzi
}

A Sociedade Pestalozzi, associação civil mantida por doações, inclusive do Estado, era "destinada a proteger as crianças e adolescentes excepcionais e a preservar a sociedade e a raça, das influências nocivas para a sua saúde mental e equilíbrio moral" (SOCIEDADE PESTALOZZI, 1939, p. 01). Auxiliou os alunos e os professores das classes especiais dos grupos escolares de Belo Horizonte, organizou um centro de diagnóstico e tratamento e o Consultório Médico Pedagógico, que realizou pesquisas 
médicas, antropológicas, psicológicas e estatísticas. A Sociedade Pestalozzi também divulgou noções teóricas e práticas sobre a infância "excepcional" e orientou em assuntos de Higiene Mental. Segundo a educadora, para o melhor ajustamento das crianças à vida social, a Psicologia deveria fornecer meios para a compreensão das formas de condutas que tendessem à harmonia interna e social. A Higiene Mental, "filha legítima da psicologia", seria o conhecimento da natureza humana e dos critérios de sua normalidade. Nesse caso, o indivíduo "normal" seria aquele capaz de adaptar-se socialmente.

(...) uma criatura em constante luta consigo mesma e com inúmeros conflitos entre seu próprio eu e o eu de outrem em perpétuo ajustamento ao meio, em que tem que desempenhar seu papel individual, dentro de uma determinada coletividade, tendendo ao equilíbrio (...) (ANTIPOFF, 1992p, p. 284).

Se o indivíduo fracassasse nos estudos, deveria procurar outras atividades em que suas aptidões fossem mais adequadas e, nesse caminho, a Higiene Mental recorreria à Educação para indicar aos indivíduos qual campo se desenvolveria melhor. Todavia, os indivíduos poderiam apresentar distúrbios e desajustamentos mais graves e, nesse caso, a permanência no meio social não seria possível:

Não há possibilidade do indivíduo permanecer no mesmo meio. São outros meios que a psiquiatria indicaria - meios menos complexos, com menores exigências, com responsabilidade diminuída para o indivíduo - e nela poderá viver, produzindo algo de útil socialmente falando. As clínicas de condutas ou de trabalho dirigido - são estes novos ambientes que substituíram os manicômios humilhantes e prisões degradantes para os loucos ou delinqüentes (ANTIPOFF, 1992p, p. 285).

Para a educadora, os preceitos da higiene mental eram frutos do estudo da natureza humana inserida num contexto social, no sentido de fornecer meios de ajustamento em situações extremas, prevenindo o conflito entre a sociedade e o indivíduo. A Sociedade Pestalozzi atuou na divulgação desses preceitos, alertando as famílias e as escolas para darem assistência, o mais rápido possível, enquanto o organismo era mais flexível para a formação de "hábitos sociais, de vida, de comunicação pela linguagem e das noções as quais o ser humano deve se ajustar ao ambiente físico e social" (ANTIPOFF, 1992r, p. 280). Para detectar os problemas biológicos e também sociais e, a partir do diagnóstico, estabelecer lugares específicos para auxiliar no ajustamento dos indivíduos, o Consultório Médico Pedagógico realizava entrevistas, testes e a classificação das crianças, procedimentos que Helena Antipoff, antes, havia desenvolvido no Laboratório de Psicologia da Escola de Aperfeiçoamento. Esses mecanismos de intervenção visavam à melhoria da raça humana e, em conseqüência, uma perfeita harmonia social, refletindo a presença das idéias eugênicas ${ }^{11}$ no Brasil.

Divulgadora dessas idéias, a Sociedade Pestalozzi vai buscar concretizá-las com a criação de instituições para atender às crianças "excepcionais": o Pavilhão de Natal (1934), o Instituto Pestalozzi (1935) e a Fazenda do Rosário (1940). A criação desse tipo de instituição estava prevista no Estatuto da Sociedade, cuja finalidade era proteger a infância no sentido de "(...) fornecer-lhe meios para melhoramento de seu estado mental, moral e social, de sorte que na idade adulta, pese ela o menos possível à sociedade" (SOCIEDADE PESTALOZZI, 1939, p. 3). 


\section{O Pavilhão de Natal}

A idéia dessa instituição surgiu da necessidade de um espaço para acolher as crianças que trabalhavam nas ruas da capital mineira, principalmente, os vendedores de jornais que, trabalhando o dia todo, não possuíam lugar para descanso. Numa palestra realizada pela Sociedade Pestalozzi, Helena Antipoff, para demonstrar a urgência de ações para resolver essa questão, enfatizou a situação dessas crianças, que a fazia lembrar fatos da miséria porque passavam os países em tempos de calamidades, estremecimentos da natureza ou agitações sociais. A educadora também citou o Código de Menores, no que se referia à questão do trabalho do menor e um inquérito, realizado com 51 meninos, vendedores de jornais, em que ficou evidente a desobediência ao que previa a legislação.

Pelo Código de Menores (1927), a jornada de trabalho de menores de 18 anos não poderia ultrapassar seis horas, com interrupções para repouso de, no mínimo, uma hora. $\mathrm{O}$ Código proibia: o trabalho noturno para os menores de 18 anos; o trabalho nas ruas, praças ou lugares públicos para meninos menores de 14 anos; qualquer tipo de trabalho para aqueles menores de 12 anos e, só poderiam ser empregados, a partir dessa idade, aqueles portadores do diploma do ensino elementar. O inquérito constatou que a idade predominante entre os vendedores de jornais era de 13-14 anos, havia uma criança de 10 anos e os meninos mais velhos tinham 16 anos. Considerando que a maioria vendia jornais há mais de um ano, todos começaram a trabalhar sem atingir a idade e a escolaridade previstas pela legislação. Dos 51 meninos, apenas 10 possuíam o curso primário, sendo que 19 estavam fora da escola. Praticamente a metade dos meninos não poderia estar trabalhando com a venda de jornais porque tinha menos de 14 anos. Sem falar que o inquérito destacou que muitos dos meninos trabalhavam até de madrugada.

Helena Antipoff solicitou um auxílio aos poderes públicos para conseguir obediência à legislação e chamou à responsabilidade os membros do Conselho de Assistência e Proteção aos Menores, criado em Minas Gerais pelo Decreto 7680, e que deveria fiscalizar e promover meios para melhorar a assistência e a educação do menor abandonado, delinqüente ou operário. Buscando melhorar a situação dos meninos trabalhadores na rua, propôs a criação e a manutenção de um lugar para oferecer um lar higiênico, servindo também de sede para a assistência educativa. O termo abrigo foi logo descartado, por reportar a algo provisório e efêmero, sem conforto e carinho para receber as crianças.

Segundo a educadora, esses meninos que trabalhavam na rua necessitavam de cuidados especiais, pois concentravam todos os fatores da delinqüência: - porque vinham de famílias miseráveis e, segundo ela, "a pobreza continuada rebaixa o plano da vida e força a família ao pauperismo e à delinqüência” (ANTIPOFF, 1992m, p. 152); - seus lares desfalcados, já que $60 \%$ dos meninos que responderam ao inquérito eram órfãos e semiórfãos e, citando estatísticas, a educadora destacou que a morte dos pais estava entre as causas mais patentes da delinqüência; - o caráter dos menores, pois muitos apresentavam taras muito graves: eram impulsivos, tinham o hábito de mentir, de furtar, de caluniar; alguns eram verdadeiros "débeis mentais" e outros bem inteligentes para explorar esta debilidade.

Diante da complexidade da educação dessas crianças, Helena Antipoff condenava a construção de um abrigo sem prever a seleção dos meninos e colocá-los sob a vigilância de profissionais competentes. Pensou num lugar que sugerisse uma ação diferente com os meninos e, por isso, o nome escolhido para a instituição foi Pavilhão de Natal, numa alusão à data em que foi lançada a construção do prédio. Contudo, não bastaria apenas mudar o nome e a aparência do lugar, uma vez que a assistência não teria apenas o propósito de abrigar os pequenos trabalhadores após o horário do trabalho na rua, mas fornecer-lhes 
uma assistência moral contra a fraqueza, o vício, a ociosidade. Para isso, o pavilhão teria um caráter de república infantil, em que os meninos seriam agrupados a partir da amizade e simpatia uns pelos outros, formando uma unidade administrativa e esse grupo teria um quarto, com oito camas, havendo quatro cômodos iguais a esse no Pavilhão. Os próprios meninos cuidariam da limpeza, organização e conforto do quarto. Helena Antipoff acreditava que as crianças sadias tinham uma tendência para a construção mais forte do que para a destruição, a menos que houvesse entre elas algumas nitidamente perversas.

A educadora chamou a atenção para o fato de que sozinhas as crianças não levariam a auto-educação muito longe, pois seria da natureza da criança deixar levar-se pelos interesses momentâneos, não se preocupando com o futuro e, por isso, haveria na instituição um Conselho Diretor, formado por três pessoas competentes e ativas que se responsabilizariam pelo trabalho, inspirando-se nos ensinamentos de Robert Stephenson Smyth Baden-Powell, criador do escotismo, e nos princípios da Escola Ativa. A opção em trabalhar com esse sistema educativo era, segundo Helena Antipoff, uma tentativa de evitar que o internato se parecesse com uma prisão. Esse procedimento não seria uma idéia original, já que a experiência com educação de meninos difíceis, em muitos países, teria mostrado que "os melhores resultados foram alcançados com o regime de liberdade, aliado ao da responsabilidade" (ANTIPOFF, 1992e, p. 31). Segundo esses princípios, os meninos seriam habituados a viver num ambiente livre e responsável, ficando de fora o castigo, os sermões, o sistema de grades e fechaduras.

Nesse contexto, os trabalhos desenvolvidos pelas crianças na rua eram de vários tipos: vendiam jornais, capinavam as ruas, cavavam, trabalhavam em oficinas, engraxavam sapatos, entre outros. A condição para ser atendido pelo Pavilhão de Natal era ser um trabalhador e "nenhum será recebido sem as credenciais de que trabalha para ganhar a vida" (ANTIPOFF, 1992e, p. 34). Mesmo já tendo um trabalho, os meninos teriam ocupações na instituição em seus horários de folga. Os quartos dos meninos que vendiam jornais, devido ao horário em que saíam para trabalhar, seriam cuidados por outros meninos, assim como haveria aqueles para a limpeza do assoalho, lavagem de roupa, serviços da cozinha. No terreno da casa, os meninos trabalhariam em jardim e hortas. Além disso, seriam organizadas as oficinas de bombeiro, eletricista, carpintaria, marcenaria, encadernação e sapataria. Essas atividades deveriam buscar o lucro, o que era indispensável para a instituição, que desejava ser independente da caridade pública e da ajuda do governo.

O Pavilhão teria um modesto campo de esportes que funcionaria das 13 às 15 horas, nos dias úteis, sendo que, em domingos e feriados, abriria em horários determinados. No período vespertino, os meninos participariam de atividades na própria instituição e, aqueles que "frequientam o curso primário poderão cursar no grupo noturno (...). Aos que possuem o diploma, será dado o trabalho à noite no gênero de grêmio ou clube" (ANTIPOFF, 1992e, p. 36). Nessas "Continuation Schools", assim as denominou Helena Antipoff, "os meninos se prepararão para galgar degraus superiores no ensino secundário ou mesmo superior, caso tenham aptidões" (ANTIPOFF, 1992e, p. 37). Helena Antipoff procurava resolver "o difícil problema da educação dos menores", com iniciativas como essa, que seriam colocadas em prática no Pavilhão de Natal, "tornando-o, se Deus quiser, um lar sem ser um orfanato, uma oficina sem ser uma escola profissional, uma casa de educação sem ser um internato-prisão" (ANTIPOFF, 1992e, p. 37).

\section{O Instituto Pestalozzi}

O Instituto Pestalozzi foi criado por meio de uma parceria com o estado de Minas Gerais, que construiu o prédio no terreno doado pela Sociedade Pestalozzi e nomeou professoras especialistas, indicadas pela Sociedade, que possuía noventa crianças 
"infradotadas" matriculadas sem escola. Em entrevista ao Estado de Minas, em 26 de outubro de 1934, Helena Antipoff apresentou as atividades do Instituto que possuía um consultório para crianças deficientes, classes especiais para educação e tratamento de crianças "deficientes", cursos especiais sobre "anormais", pesquisas científicas sobre as causas e tratamento dos "anormais", centro de informação e estatística relativas aos "excepcionais", redação de revistas e publicações, centro de educação e propaganda eugênica, centro de orientação profissional de deficientes, assistência à infância "excepcional" e socialmente abandonada.

As professoras do Instituto eram ex-alunas de Helena Antipoff, novatas no atendimento às crianças "excepcionais" e atuavam sob a orientação da educadora junto ao externato, que recebia alunos que nada ou pouco progrediam nos grupos escolares da capital mineira. Além dessas crianças de Belo Horizonte, famílias de outras cidades procuravam, constantemente, a instituição e, em função disso, a educadora criou os "Pequenos Lares", em uma casa alugada nos arredores do Instituto, para receber os pensionistas que ficavam hospedados, sob a direção das professoras do Instituto Pestalozzi.

A instituição recebeu entre seus primeiros alunos, em regime de semi-internato, os meninos que estavam no Abrigo de Menores Afonso de Moraes que eram "bastante inteligentes, porém filhos da rua, apresentavam, em sua maioria, condutas anti-sociais de extrema agressividade, representando perigo muitas vezes para seus colegas e educadores" (ANTIPOFF, 1992r, p. 238). Com o intuito de diminuir a miséria moral, Helena Antipoff estabeleceu como base de todo o trabalho pedagógico o conhecimento amplo de cada criança, principalmente porque havia uma variedade muito grande de tipos humanos entre os meninos atendidos pelo Instituto Pestalozzi, o que dificultava a tarefa do educador em "auxiliar cada um na sua existência, preparando a vida de cada um no meio da sociedade para a qual a adaptação é hoje tão difícil” (ANTIPOFF et al., 1958, p. 21).

$\mathrm{Na}$ rede pública de ensino, Helena Antipoff preconizou a aplicação de mais de um tipo de teste psicológico para a classificação dos "excepcionais" (o Método de Experimentação Natural, os Testes de Inteligência Binet-Simon, o Método de Inquérito e a Observação). Nas instituições de assistência aos menores, o objetivo era o reajustamento da conduta dos "excepcionais" e, para alcançar maior êxito, seria necessário conhecer "o estado biológico do seu organismo, suas tendências, suas capacidades físicas e psíquicas, assim como o mecanismo exato do seu funcionamento" (ANTIPOFF et al., 1958, p. 16). Para esse fim, a Experimentação Natural seria a metodologia por excelência, já que os testes receberam críticas da educadora por serem realizados em situações artificiais, nas quais o indivíduo reagia também de maneira artificial e, em se tratando "de um paciente inteligente, sua perspicácia the ditará a resposta que dele 'exige' o experimentador" (ANTIPOFF et al., 1958, p. 16). Quanto à observação, a dificuldade estaria na falta de precisão, uma vez que as situações observadas eram muito complexas para se isolar os elementos que constituíam o caráter de cada indivíduo. Apesar dos problemas apontados, a educadora destacou as vantagens desses métodos e elegeu a Experimentação Natural como a mais adequada para o acompanhamento das crianças "excepcionais", justamente por conjugar essas vantagens: os testes possibilitariam ao experimentador provocar situações específicas e precisar a avaliação, enquanto a observação traria a neutralidade e a condição para um trabalho contínuo.

A experimentação natural, metodologia desenvolvida pelo psicólogo russo Alexandre Lazursky, a partir da observação dos alunos em suas atividades escolares, consistia em observar e escolher comportamentos do indivíduo, a partir de atividades reais e, a cada reação típica, atribuir uma significação caracterológica que, segundo a intensidade da manifestação, avaliava o grau da reação psicológica. Além de estudar o indivíduo em situações reais, outra vantagem do método seria a possibilidade de ser aplicado em qualquer ambiente, impondo-se, principalmente, onde fosse necessário 
conhecer o comportamento de um grupo de indivíduos. A educadora já havia utilizado esse método no Maison Des Petits, em Genebra, onde as crianças, entre 6 e 8 anos, foram estudadas através dos trabalhos manuais. No Instituto Pestalozzi, o trabalho manual também foi alvo de atenção.

Chegamos a considerá-lo matéria educativa de primeira grandeza. Encaramos o trabalho manual não só como um meio de ensinar aos nossos alunos técnicas úteis para sua vida de adultos, mas como uma fonte de revelações para o seu mais profundo conhecimento e como um instrumento poderoso para a sua formação, intelectual, social e moral (ANTIPOFF, et al., 1958, p. 21).

Desde o início das atividades do Instituto, em 1935, o programa de atividades educativas contava, além das matérias escolares e dos exercícios de ortopedia mental, com o ensino de trabalhos manuais, ensino técnico-profissional das oficinas e o trabalho doméstico, sendo este último "provocado pela necessidade, pois o Instituto Pestalozzi não contava, entre seu pessoal, nenhum servente para limpeza da casa e outros serviços caseiros" (ANTIPOFF et al., 1958, p. 22). Os serviços domésticos foram distribuídos em oito modalidades, ordenadas da mais simples e fácil de executar à mais difícil ${ }^{12}$, as quais nem todos os meninos conseguiam realizar por exigirem maior força muscular, inteligência e habilidades. Em torno de quarenta meninos do Abrigo de Menores, que tinham entre $10 \mathrm{e}$ 18 anos, trabalhavam nesses serviços de limpeza.

Em algumas atividades, a utilização da vassoura era suficiente para realizá-la, mas outras exigiam maiores habilidades como, por exemplo, vasculhar a casa, em que a criança precisava de escada para alcançar os lugares mais elevados. A enceração era considerada a atividade mais complexa na escala de dificuldades e aqueles meninos que aprenderam a encerar o assoalho e os azulejos do Instituto, prestavam serviço em casas particulares, sendo que as gratificações recebidas eram depositadas na conta do Instituto.

As atividades desenvolvidas internamente também eram remuneradas e os meninos podiam gastar na compra de objetos a venda na própria loja do Instituto (material escolar, frutas, doces, etc.). Num primeiro momento, todos os meninos recebiam a mesma quantia, porém, devido às diferenças no rendimento das tarefas, passou-se a fazer uma avaliação da eficiência do trabalho e a remuneração começou a ser diferenciada. Aos poucos, foram introduzidas fichas individuais do trabalho, em que os alunos recebiam notas de acordo com o seu desempenho, referente à rapidez no trabalho, ao método, à perseverança, ao cuidado com o material, à iniciativa, à responsabilidade, ao humor durante o trabalho, à habilidade e ao capricho. Essas fichas serviam de critério para remuneração, orientavam as professoras no melhor conhecimento dos alunos e os guiavam no aperfeiçoamento de suas capacidades e do seu caráter, tornando-se uma parte importante na pedagogia da instituição, pois os meninos compreendiam melhor o que se esperava para serem considerados bons trabalhadores.

Ao acompanhar os resultados das fichas de trabalho, num período de seis meses, Helena Antipoff concluiu que houve uma melhoria significativa na conduta dos meninos durante o trabalho doméstico, constituindo-se "um meio satisfatório de avaliação de conduta de certos traços de caráter, servindo de método de treinamento e de controle da aprendizagem dos jovens retardados e desajustados" (ANTIPOFF et al., 1958, p. 31).

O desenvolvimento das crianças também era acompanhado pelo setor psicométrico e antropométrico, onde havia discussões dos casos com a participação de outros especialistas. Entre estes, estavam os médicos Santiago Americano Freire, Aureliano Tavares Bastos e Clóvis Salgado, que fizeram experimentações com hormônios em alguns meninos do Instituto Pestalozzi; o pediatra Fernando Magalhães Gomes tornou-se adepto do tratamento medicamentoso ensaiado na instituição (ANTIPOFF, 1975). 
$\mathrm{Na}$ avaliação de Helena Antipoff, obras como o Instituto Pestalozzi, que se dedicavam ao conhecimento e tratamento da infância "excepcional", prestavam um eficiente serviço à sociedade.

A existência de classes especiais que recolhem alunos sem proveito escolar com isto diminuindo o peso morto do trabalho pedagógico contribui bastante para intensificar o ritmo dos processos educativos da massa de crianças comuns. Tomemos como prova disto com o Instituto Pestalozzi que recolhendo cerca de 200 crianças dos grupos vizinhos facilitou seu trabalho (ANTIPOFF, 1992o, p. 141).

No Instituto, os "excepcionais" tinham a possibilidade de concluir o ensino primário, além de iniciar algum ofício que lhes permitisse exercer uma atividade remunerada ao deixarem a instituição. Todavia, não eram todas as crianças que conseguiam concluir o ensino primário ou se profissionalizar, ou mesmo aquelas que concluíam, não tinham condições de deixar a instituição, algumas permaneciam no estabelecimento até alcançarem uma idade avançada sem que se conseguisse um "ajustamento social para uma existência menos dependente da família e do Estado" (ANTIPOFF, 1992q, p. 274). Foi para atender a essas crianças que a Sociedade Pestalozzi adquiriu uma propriedade no campo, onde se instalou a Fazenda do Rosário.

\section{A Fazenda do Rosário}

O local para a instalação dessa instituição foi um sítio de 45 alqueires de terra, a 25 quilômetros de Belo Horizonte. No início de janeiro de 1940, a Sociedade Pestalozzi enviou para a referida Fazenda seus primeiros moradores: a Diretora, Yolanda Barbosa; a primeira professora, Cora de Faria Duarte; seis meninos do Abrigo de Menores e do Instituto Pestalozzi de Belo Horizonte; o senhor João Costa que auxiliava as professoras nos encaminhamentos com os internos.

As aulas do curso primário, destinadas aos alunos internos e externos, vindos da vizinhança, tiveram início em fevereiro de 1940, com a abertura da Escola Dom Silvério. Em 1942, foi adquirida uma propriedade anexa, que ficou conhecida como Chacrinha, onde se instalou um internato. Até 1942, o perfil dos internos era constituído pelos "excepcionais sociais", quer dizer, aqueles classificados por sua conduta ou seu caráter, incluindo os meninos abandonados pela família ou pelo responsável. A partir de 1942, a instituição passou a receber os "excepcionais orgânicos", ou seja, aqueles cujo desenvolvimento mental se apresentava aquém ou além do padrão estabelecido para crianças da mesma idade e aqueles portadores de distúrbios de origem hereditária.

De acordo com o relatório da diretora Yolanda Barbosa, entre 1940 e 1952, foram atendidos 343 alunos, sendo que 121 ainda encontravam-se internados ${ }^{13}$. Do total de alunos atendidos, incluídos aqueles que ainda encontravam-se na instituição, 116 alunos, $34 \%$, foram internados por motivo de abandono social e falta de recursos financeiros, sendo que órfãos de pai e mãe eram 47 e aqueles cujos pais eram desconhecidos 69. Quanto aos outros 227 internos, foram indicadas outras motivações para a internação, que se referiam ao diagnóstico feito pela Sociedade Pestalozzi, entre os alunos atendidos na capital mineira. No início do ano, a diretora da Fazenda do Rosário notificava o presidente da Sociedade sobre as vagas existentes e este encaminhava à instituição os casos mais urgentes. Muitos meninos foram encaminhados à instituição pela polícia e nada sabiam sobre seus pais.

Os diários nos levaram para o interior da Fazenda do Rosário e nos possibilitaram ampliar o olhar a respeito do tratamento recebido pelos internos. Embora esses diários 
tenham apontado os meninos sendo destacados para aulas, são raros os momentos em que essa proposta pedagógica aparece no histórico da Fazenda do Rosário. Esse fato não indica que as aulas não aconteciam, mas que Helena Antipoff, ao apresentar as atividades da instituição, destacou outra proposta de ação para formação de seus alunos. Tratava-se da educação edificada pelo trabalho, voltada para o trabalho, buscando a "formação de gerações melhor preparadas para a produção técnico-econômica, agrícola e artesanal" (ANTIPOFF, 1992s, p. 171).

Os primeiros internos chegaram à fazenda no início de janeiro de 1940 e, já no dia 09 daquele mês, "os meninos receberam a distribuição dos serviços que está à parede da cozinha para lhes lembrar os deveres. Cada qual ficou encarregado de um trabalho, e ontem deram conta satisfatoriamente das obrigações" (BARBOSA apud ANTIPOFF, 1953, p. 02). O senhor João Costa era quem distribuía os alunos pelos diversos trabalhos de capina, conserto de cercas, de porteiras, entre outras atividades rurais ${ }^{14}$. O dia de trabalho começava cedo para eles: "ontem, às 5 horas e meia da manhã já se ouvia a vozeria alegre dos meninos, que já são sete, tomando leite no curral" (MELO apud ANTIPOFF, 1953, p. 2). As atividades escolares propriamente ditas ficavam em segundo plano. Afirmamos isso, baseando-nos nos trechos dos diários destacados por Helena Antipoff que, além de darem maior importância ao trabalho agrícola executado pelos meninos, demonstraram que as atividades escolares não eram prioridades nos deveres dos internos: "Como amanheceu chovendo (...) fiquei só com os meninos, os quais não podendo fazer o trabalho de conserto da estrada e capina, ficaram lendo, escrevendo" (BARBOSA apud ANTIPOFF, 1953, p. $05)$.

É significativa uma passagem do diário de Helena Antipoff, na qual ela escreveu sobre um aluno que estava saindo da instituição um ano após sua chegada e cuja mestra se preocupava com a formação incompleta do menino, nesse período em que passou na fazenda: "Queria eu que terminasse ao menos o ciclo inteiro da construção que iniciou, britando pedra, devia aprender pelo menos o reboco, a fim de ganhar mais no emprego" (ANTIPOFF, 1953, p. 20). O ciclo inteiro não se referia ao ensino primário completo e sim ao aprendizado da profissão de pedreiro. Apesar dos diários apontarem para a existência de pedreiros adultos, as crianças também ajudavam nas construções dos prédios da instituição.

02/11/40 - (...) Na ausência do "Vovô", o pedreiro, seu filho Floriano está na direção da Casa de Repouso em construção (...). Mas, por que então, Geraldo Lopes estará na lavoura, ele que é tão bom no serviço de pedreiro? Não combinou com Floriano? Na "reunião" trataremos do caso do "abandono espontâneo" do serviço. Mas de quem é a culpa, do menino ou do mestre? (ANTIPOFF, 1953, p. 15).

Com base nesses diários, inferimos que as crianças eram obrigadas a desempenhar o trabalho para o qual estavam designadas. Visando criar nos meninos o hábito do trabalho e educá-los no aspecto econômico, ficou estabelecido que, a partir de fevereiro de 1940, eles seriam remunerados e o valor a ser pago a cada um estaria vinculado à prontidão com que desempenhassem o trabalho, ao bom humor, à produção, à iniciativa útil e à invenção de algum processo original que melhorasse a realização das tarefas. Os próprios meninos estabeleciam as bases de julgamento, com a aprovação dos professores. Ficou acertado que eles receberiam apenas metade dos valores merecidos e a outra parte seria depositada na Caixa Econômica. Em fevereiro de 1940, dois alunos deixaram para a instituição a maior parte do dinheiro recebido, o que foi considerado, por uma das professoras, um bom sinal.

O crescimento dos meninos - a maioria contava com idades entre 17 e 18 anos preocupava as professoras, pois acreditavam que, com a aproximação da idade adulta, pouco poderia ser feito para modificá-los. Preocupavam-se com a adaptação dos meninos à vida adulta, principalmente, com a escolha da profissão, já que elas constataram que a 
maioria tinha pouca inclinação para a vida do campo e para o cultivo da terra. O internato da "Chacrinha" destinava-se, justamente, ao atendimento desses meninos de "maior idade". Os trechos dos diários referentes aos acontecimentos na Chacrinha enfocaram o trabalho realizado pelos meninos e não deram destaque para as atividades escolares. Uma única sala servia de refeitório, sala de jogos, sala de aula e sala de estudos, os quais se realizavam à noite, indicativo de que, nesse novo espaço, as atividades escolares também ficavam em segundo plano.

A respeito das atividades escolares, é interessante observar o diário de uma professora que relatou o episódio em que um aluno da Chacrinha quis mandar uma carta à mãe, pedindo para ir buscá-lo e, para tanto, ditou a carta para a professora que a escreveu e, em seguida, o aluno copiou o conteúdo. A professora não explicou em seu diário por que a escrita da carta se processou a partir da cópia, não informou qual a idade do menino, qual a sua trajetória antes de chegar à Chacrinha, nem há quanto tempo estava na instituição. Considerando que nesse momento os "excepcionais orgânicos" ainda não eram atendidos na instituição, acreditamos que o aluno não era alfabetizado, conseguindo apenas fazer cópia do texto e que a prioridade na instituição não era ensinar a ler e escrever, mas preparar para o trabalho. Além do local onde desenvolviam seus trabalhos, a vida dos meninos não mudou, a rotina continuava muito parecida, pois, com exceção da cozinheira, não havia empregados, estando todas as atividades sob responsabilidade dos meninos.

(...) Sem empregados, exceto a cozinheira, todos os trabalhos domésticos, de horta, jardim e de criação de animais e outros se fazia exclusivamente pelos meninos. Obedecendo a uma distribuição semanal de tarefas que se especificava no quadro na única sala servindo de refeitório, sala de aula, de capela, e de salão de jogos e estudos todas as noites - os meninos, no horário previsto, se distribuíam pelas tarefas individualmente, ou em grupos, para cumprir com suas obrigações (ANTIPOFF \& BARBOSA, 1992, p. 129).

A partir de fevereiro de 1942, a Fazenda do Rosário passou a receber os "excepcionais orgânicos”, quer dizer, “(...) também começam a entrar os meninos retardados, às vezes fortemente prejudicados, já pela hereditariedade, já pelos acidentes sofridos desde a tenra idade" (ANDRADA apud ANTIPOFF, 1953, p. 26). "Excepcionais orgânicos" e "sociais" (CAMPOS, 2002), para ambos, o mesmo tipo de atividade: o trabalho; a diretora Yolanda Barbosa apontou que poucos desses meninos se apresentavam amadurecidos para fazer o trabalho integralmente e com a necessária independência, sendo que a maioria era capaz de executar tarefas ou parte do trabalho.

A distribuição do trabalho era feita semanalmente e cada interno ficava responsável por determinada tarefa e, ao final desse período, os meninos eram reunidos para avaliação de desempenho, recebendo cada um a sua nota, que variava de 0 a 5 , na ficha que acompanhava o trabalho realizado e, para melhor controlar os internos, eram considerados dois pontos: o interesse pelo trabalho - prontidão em começá-lo, resistência, capacidade para executá-lo, capricho; e a disciplina - ordem, bom humor, iniciativa. Yolanda Barbosa justificou que o trabalho era utilizado para ensinar ofícios aos alunos, para conhecer a aptidão de cada interno para determinados trabalhos e, também, como meio de educá-los social e moralmente e, por isso, essa necessidade de controlar suas atividades. A diretora destacou os trabalhos executados pelos meninos semanalmente, apresentando-os a partir do mais simples:

1) Rasgar palha; 2) Catar esterco; 3) Bater esterco; 4) Transportar lenha; 5) Debulhar milho; 6) Varrer o pátio e os caminhos; 7) Varrer as varandas; 8) Varrer os refeitórios; 9) Varrer os quartos; 10) Tirar poeira; 
11) Lavar a casa; 12) Arrumar as estantes; 14) Capinar; 15) Preparar terreno para o plantio; 16) Plantar; 17) Cuidar dos animais; 18) Cuidar da horta; 19) Cuidar do jardim; 20) Servente de pedreiro; 21) Cooperar; 22) Fazer mandados; 23) Fazer balaios de bambu; 24) Fazer cestos de barbante; 25) Fazer cestas de cambaúba; 26) Fazer cestinhas de Jaraguá; 27) Enrestar cebola e alho; 28) Aprender ofício de sapateiro; 29) Tomar conta da rouparia; 30) Cuidar dos alunos mudos (ANTIPOFF \& BARBOSA, 1992, p. 131).

Os alunos eram divididos em turmas e cada uma tinha um chefe ou responsável e, "além do trabalho de limpeza e jardim, as turmas são obrigadas a trabalhar na lavoura ou fazer qualquer trabalho extraordinário na Fazenda" (ANTIPOFF \& BARBOSA, 1992, p. 137 - grifos nosso). De acordo com as necessidades institucionais, os meninos da Chacrinha também trabalhavam em outras instalações da Fazenda do Rosário.

Não havia uma distinção entre os encaminhamentos relacionados aos "excepcionais orgânicos" ou aos "sociais", nem as crianças menores recebiam um tratamento diferenciado, trabalhavam como as crianças maiores, servindo de exemplo para aquelas que não se adaptavam aos trabalhos realizados por elas. Já as aptidões, podiam se revelar a partir de um rol de possibilidades previamente estabelecido, ao qual a criança era obrigada a se adaptar. De acordo com Yolanda Barbosa, o início desse processo não se deu sem conflitos: "(...) eu estive a ponto de pensar que era impossível controlar esse grupinho tão variado de idade, caráter e educação" (ANTIPOFF \& BARBOSA, 1992, p. 137).

Com a implantação das fichas de acompanhamento dos trabalhos, o relatório da diretora Yolanda Barbosa apresentou indicativos de uma melhora no desempenho dos internos, destacando alguns meninos que se submetiam ao trabalho sem nenhuma resistência. O pagamento estava vinculado ao desempenho e esse critério é fundamental para compreendermos o comportamento daqueles que se dedicavam exemplarmente ao trabalho. Contudo, a atitude positiva frente ao trabalho não se estendeu a todos, sendo que aqueles que apresentavam alguma forma de resistência eram chamados de preguiçosos.

No histórico da Fazenda do Rosário, apresentado por Helena Antipoff, em 1962, a educadora falou desses primeiros anos de funcionamento e assim resumiu as atividades da Escola Dom Silvério e ao internato da Chacrinha: “(...) Localizadas em sítios e chácaras, oferecia o internato a seus alunos vários campos de ocupações produtivas e educacionais a uma só vez (...)" (ANTIPOFF, 1992q, p. 275).

Resta saber a quem essas ocupações eram produtivas, porque os diários analisados evidenciaram que, para os meninos, essas ocupações não eram produtivas e, muito menos, educativas. Os meninos não tinham aptidões para os trabalhos no campo, nem preparo físico para tanto; não estavam ali por vontade própria, apresentando diversas formas de resistência; aqueles que se submetiam ao trabalho, o faziam sob constrangimento imposto pela avaliação de desempenho, à qual estava vinculada a remuneração; as atividades escolares ficavam em segundo plano, pois eram realizadas após os horários de trabalho ou em dias em que não era possível a realização dos trabalhos da fazenda; não havia um local específico para ministrar as aulas; o mesmo tratamento era dispensado a todas as crianças, fossem "maiores" ou "menores", "excepcionais orgânicos" ou "sociais"; todos os meninos eram obrigados a fazer um rodízio pelas atividades de limpeza, capina, horta, lavoura, jardim. Um texto escrito por Helena Antipoff (1992o), ajudou-nos a esclarecer para quem essas ocupações eram produtivas.

A assistência ao ser humano infranormal, fraco e desajustado, na coletividade civilizada, não é somente uma prova moral de solidariedade, em que o homem são e forte presta seu auxílio em nome dos princípios perenes de respeito à pessoa humana - é também fruto da convicção de 
que servindo à criança mesmo que consideravelmente diminuída no seu potencial psíquico por fatores hereditários ou pela ocorrência de acidentes da primeira infância - se realiza uma obra eficiente ao serviço da sociedade (ANTIPOFF, 1992o, p. 140).

O atendimento aos "excepcionais" representava um eficiente serviço à sociedade formando-os moralmente, para que se adaptassem aos padrões sociais e não se transformassem em "rebotalho humano miserável, que enche os hospitais, os manicômios, as prisões" (ANTIPOFF, 19921, p. 49). Para endossar a importância dessa formação moral dos meninos "excepcionais" para a sociedade em que vivem, Helena Antipoff reportou-se às classes especiais da Alemanha, em que os ex-alunos compareciam menos aos tribunais judiciários. Além disso, a assistência aos "excepcionais" prestava um serviço à sociedade na medida em que os preparava para serem capazes de ganhar a vida, quer dizer, torná-los aptos para o trabalho, para que pudessem sobreviver independentes da ajuda do Estado e da sociedade.

\section{A Educação e o Trabalho: uma análise a partir de Marx e Gramsci}

Nas instituições criadas por Helena Antipoff, desde a Sociedade Pestalozzi, o trabalho foi o fio condutor do processo educativo, que visava preparar os internos para o trabalho. Estabelecemos um posicionamento crítico frente aos princípios científicos que fundamentaram essa educação pelo e para o trabalho, desde o método para "selecionar" os meninos "excepcionais" encaminhados às instituições, até a forma de organização das atividades, que obrigava os meninos a desempenhar funções pré-estabelecidas. Tratamos, agora, de discutir a questão da união ensino e trabalho a partir de categorias que, ampliando nossa visão sobre esse processo, nos ajudaram aprofundar e fundamentar as críticas que apresentamos a partir dos dados empíricos, num esforço de análise que busca o rigor científico, sobretudo na perspectiva de uma leitura do passado sem um viés anacrônico.

Para essa análise, recorremos a Karl Marx, para quem o fim da educação, a partir da união ensino e trabalho, é formar o Homem "Omnilateral", e a Antônio Gramsci, cujo princípio educativo une ensino e trabalho para formar o Homem Dirigente. Com o apoio desses autores, apreendemos categorias que ampliaram nossa visão sobre esse processo e permitiram uma análise crítica das atividades dessas instituições.

MANACORDA (1991) indaga se existe e como se configura uma pedagogia marxiana, concluindo que, no Manifesto Comunista, Marx estabelece o princípio educativo da "unificação do ensino com a produção material", desde que fossem excluídos, através de intervenção política, os aspectos alienantes da fábrica capitalista, pois, só assim a fábrica poderia desenvolver sua função libertadora (MANACORDA, 1991, p. 20-26).

Vinte anos após o Manifesto Comunista, no documento "As Instruções aos Delegados", Marx, apesar de destacar a maneira horrível como se realiza a tendência da indústria moderna de incluir na produção crianças e adolescentes, a considera progressiva e endossa a tese de que, a partir dos 9 anos de idade, toda criança deve se tornar um operário produtivo e, para isso, fez uma divisão das crianças por idade em três grupos: dos 9-12, 13 15, 16-17; com os respectivos horários diários de trabalho: 2, 4, 6 horas. Marx elabora uma definição do conteúdo pedagógico do ensino socialista, que deveria contemplar o ensino intelectual, a educação física e o adestramento tecnológico, "que transmita os fundamentos científicos gerais de todos os processos de produção e introduza a criança e o adolescente no uso prático e na capacidade de manejar os instrumentos elementares de todos os ofícios" (MARX apud MANACORDA, 1991, p. 27). Esse ensino é declarado válido para todas as crianças. Para Marx, a tecnologia possui uma base revolucionária, modificando, 
constantemente, os processos de produção, trazendo variações no trabalho, deslocando o operário para outros locais. Contudo, na sociedade capitalista, trata-se de uma ciência operativa, separada do trabalhador que lhe demanda uma versatilidade sem conteúdo, tornando-o "unilateral". Nesse sentido, não bastaria combinar com o trabalho de fábrica apenas o ensino elementar, já que seria preciso garantir que, nas escolas dos operários, fosse ministrado o ensino tecnológico teórico e prático, de forma a superar a ruptura entre a ciência e o trabalho. Para isso se tornar realidade, Marx proclama "a conquista do poder político pela classe operária” (MARX apud MANACORDA, 1991, p. 30).

Manacorda destaca duas categorias importantes para compreensão do princípio educativo marxiano. Trata-se da distinção entre o ensino politécnico e o ensino tecnológico. O primeiro diz respeito às escolas historicamente existentes, cujo ensino não modifica a relação de trabalho do operário, apenas o prepara para os vários trabalhos ou para as variações dos trabalhos. Esse ensino não proporciona uma formação unificada entre teoria e prática e, com isso, impossibilita uma plena e total manifestação do homem, independentemente das suas ocupações específicas. O ensino tecnológico proporciona isso, uma vez que "sublinha, com sua unidade de teoria e prática, o caráter de totalidade ou omnilateralidade do homem, não mais dividido ou limitado apenas ao aspecto manual ou apenas ao aspecto intelectual da atividade produtiva" (MANACORDA, 1991, p. 32).

A concepção marxiana identifica o trabalho com a essência humana, uma vez que "a primeira realidade histórica é a produção da própria vida material e isso constitui um fato histórico, uma condição fundamental de toda a história (...)" (MARX, 1965, p. 23), de modo que, sem o trabalho, a vida não subsistiria. Assim, não se trata de suprimir o trabalho em si, mas "a subordinação servil dos indivíduos à divisão do trabalho, e, portanto, o contraste entre trabalho intelectual e físico (...)" (MARX apud MANACORDA, 1991, p. 39). A partir desse pressuposto, Manacorda conclui que a tese marxiana não reduz o trabalho a objetivos meramente profissionais, com função didática como instrumento de verificação das noções teóricas ou, ainda, com fins morais de educação do caráter e da formação de uma atitude de respeito em relação ao trabalho e ao trabalhador. Para Marx, o objetivo da educação é o desenvolvimento completo do homem, definido como "omnilateral" e se realiza sobre a base do trabalho, já que sendo este atividade vital humana, no trabalhador está contida também uma possibilidade humana universal, que é a "omnilateralidade" (MANACORDA, 1991, p. 67-68). A partir dessas distinções - "ensino tecnológico / politécnico", "omnilateralidade / unilateralidade" - analisamos a educação pelo trabalho praticada nas instituições criadas pela Sociedade Pestalozzi.

As principais atividades desenvolvidas nessas instituições foram as atividades domésticas e o trabalho agrícola, nos quais os meninos eram obrigados a desempenhar o trabalho para o qual estavam designados, sendo que o ensino escolar ficava em segundo plano. Esse encaminhamento se distancia do ensino tecnológico preconizado pelos princípios marxianos, uma vez que não une a teoria e a prática, mantendo o trabalhador parcialmente formado no trabalho manual, sem, no entanto, ter acesso ao aspecto intelectual da atividade produtiva. Sendo assim, os meninos das instituições tinham vivência prática do trabalho, mas não adquiriam seus fundamentos científicos. Nesse aspecto, eram formados para trabalhar, executando tarefas pré-determinadas, não adquirindo habilidades para alterar sua relação com o trabalho. A união entre ensino e trabalho visava à formação do caráter e à profissionalização dos meninos e, ainda, à construção de uma relação de respeito frente ao trabalho, para que, em última instância, alcançassem uma maior adaptação à sociedade, que, ao contrário do que pensava Marx, não caberia ser transformada, já que os meninos eram encaminhados à instituição justamente para manter a ordem social estabelecida.

Lembramos que, no sentido marxiano, o homem se distingue dos animais pelo trabalho, agindo voluntária e conscientemente com base num plano, transformando a 
natureza e se transformando nesse processo. Quando as ações humanas ocorrem apenas numa esfera de adaptação a uma realidade pré-estabelecida, o que se perde é a capacidade específica dos seres humanos de agir voluntária e conscientemente, quer dizer, perde-se, exatamente, a sua distinção dos animais.

No perfil dos meninos atendidos, o recorte de classe é claramente estabelecido, principalmente a partir do conceito de "excepcional social" praticado por Helena Antipoff: aqueles cujas condições de vida familiar ou social impediam uma adequada estimulação, geralmente meninos abandonados, vindos dos abrigos em Belo Horizonte que, uma vez institucionalizados, recebiam formação para ingressar imediatamente no mercado de trabalho, já que eram considerados inaptos para prosseguir nos estudos acadêmicos. Era uma educação pelo e para o trabalho, que não se destinava a todas as crianças, mas para aquelas advindas de uma classe específica, cuja perspectiva de vida egressa era prédeterminada.

Apesar do destino dos meninos estar estabelecido mesmo antes de sua chegada à instituição, a necessidade de se conhecer a aptidão de cada um deles constituía uma justificativa para a utilização do trabalho como meio educativo e, dessa maneira, partia-se do pressuposto de uma disposição natural que precisava ser descoberta. Esse desenvolvimento espontâneo é, na perspectiva marxiana, por si mesmo parcial, pois não coloca o indivíduo frente ao mundo concreto e das relações sociais; colocado frente a si mesmo, as modificações físicas e sociais acontecem apenas individualmente, o que para Marx não interessa, uma vez que "o jovem e o homem encontram sempre o mundo pronto e acabado, daí que nada mais façam que 'descobrirem a si mesmos'; não se faz absolutamente nada "para que alguma coisa possa ser encontrada" (MARX apud MANACORDA, 1991, p. 106). Nas instituições aqui analisadas, até a "descoberta de si mesmo" acontecia de forma parcial; as possibilidades de trabalho apresentadas aos meninos restringiam-se a operações mecânicas, a trabalhos manuais, como varrer, encerar, capinar, plantar, colher, cuidar da horta, servir aos pedreiros.

Quando efetuamos nossa crítica às atividades desenvolvidas nessas instituições, não desconsideramos que, no período analisado (décadas de 1930 e 1940), o acesso à escolarização era restrito e que, portanto, boa parte da população ficava excluída desse processo. No entanto, não consideramos a impossibilidade de acesso à escola como referência que justifique uma análise positiva das atividades das instituições.

Helena Antipoff, ao se preocupar com a educação daqueles considerados "excepcionais", não questiona as condições sociais que engendram o perfil de "excepcionalidade", sendo que, seus instrumentos de trabalho, principalmente os testes psicológicos, justificam a manutenção desses perfis.

Partimos também para uma leitura gramsciana, que possui uma fundamentação mais cultural da relação ensino-trabalho, constituindo-se num desenvolvimento das teses marxianas (MANACORDA, 1991, p. 137-138). Gramsci não considera a inserção da criança na produção, sua idéia é desenvolver a capacidade de trabalho, num processo coordenado com a fábrica, mas dela separado e, nesse aspecto, enxergamos um avanço em relação às idéias marxianas. Além disso, Gramsci é contemporâneo ao Movimento Renovador e suas considerações a esse respeito mostram uma postura crítica, oferecendo, assim, uma contribuição importante para o nosso trabalho, no sentido de apreendermos essas críticas, verificando se são pertinentes para auxiliar a fundamentar as nossas, no esforço contínuo de realizar, a partir do presente, uma leitura do passado sem cair em anacronismos. Ao analisar esse contexto, Gramsci percebeu uma tendência de se restringir as escolas formativas a uma pequena elite que não precisava se preocupar com a formação profissional e, paralelamente, havia a difusão das "escolas profissionais especializadas, nas quais o destino do aluno e sua futura atividade são pré-determinados" (GRAMSCI, 1978, p. 118), sendo que o mais paradoxal é que esse tipo de escola era apresentado como 
democrática. Acreditamos que isso se aplica às instituições aqui investigadas, no sentido de que "na realidade, não só é destinada a perpetuar as diferenças sociais, como ainda a cristalizá-las em formas chinesas" (GRAMSCI, 1978, p. 136).

Para Gramsci, escolas profissionais engendram a estratificação social, pois se destinam a perpetuar determinadas funções, a partir de uma especialização unilateral do trabalho, permitindo a qualificação do trabalhador, sem suprimir a discriminacão que se revela no fato de cada grupo social ter a sua escola, tendendo assim "a eternizar as diferenças tradicionais" (GRAMSCI, 1978, p. 137). Verificamos essa estratificação quando observamos a trajetória dos egressos da Fazenda do Rosário. Dos 222 meninos que deixaram a instituição até 1952, apenas 9 deles, ou seja, cerca de $4 \%$, continuaram os estudos, ingressando no ensino secundário. Os demais, ou seja, 96\%, concluíram, apenas, o ensino primário (BARBOSA, 1953).

Gramsci propõe a Escola Única, como alternativa para a mudança desse processo de estratificação e discriminação:

(...) Escola Única de cultura geral, humanista, formativa, que equilibre equanimemente o desenvolvimento da capacidade de trabalhar manualmente e o desenvolvimento das capacidades de trabalho intelectual. Deste tipo de escola única, através de repetidas experiências de orientação profissional, passar-se-á a uma das escolas especializadas ou ao trabalho produtivo (GRAMSCI, 1978, p. 118).

A Escola Única de Gramsci corresponde ao período da escola elementar e média, sendo que o grau elementar teria no máximo quatro anos e contemplaria, além do ensino das noções instrumentais de instrução, como ler, escrever, fazer contas, geografia, história, deveria conter as primeiras noções de Estado e Sociedade, "como elementos primordiais de uma nova concepção do mundo que entra em luta contra as concepções determinadas pelos diversos ambientes sociais tradicionais (...)" (GRAMSCI, 1978, p. 122). A segunda parte do curso deveria durar por volta de seis anos e seria decisiva, pois visaria à criação de valores como "autodisciplina intelectual e a autonomia moral necessárias a uma posterior especialização, seja ela de caráter científico (estudos universitários) seja de caráter práticoprodutivo (indústria, burocracia...)" (GRAMSCI, 1978, p. 124).

Para Gramsci, a união entre ensino e trabalho não significa a aprendizagem técnica e preparação mecânica para o mercado de trabalho, representa a aquisição de hábitos adequados para lidar no mundo do trabalho, num processo que deve se iniciar desde a primeira infância e se estender até aos 16-18 anos, rejeitando qualquer profissionalização até a finalização dessa formação.

A Escola Única, buscando criar o hábito de estudo e a formação da personalidade das crianças, é marcada por uma postura disciplinar imposta de fora, pressuposto insubstituível ao futuro exercício da autodisciplina e autonomia, já que, para Gramsci, estudo é também um trabalho:

Deve-se convencer a muita gente que estudo é também um trabalho, e muito fatigante, com um tirocínio particular próprio, não só muscularnervoso, mas intelectual: é um processo de adaptação, é um hábito adquirido com esforço, aborrecimento e mesmo sofrimento (GRAMSCI, 1978, p. 137-138).

Apresentamos essa citação em contraponto direto aos fundamentos da Pedagogia Nova, endossados por Helena Antipoff, que acreditava existir na criança todo o potencial humano e a educação deveria ajudar apenas no desenvolvimento do que se possui latente, deixando operar as forças espontâneas na natureza. Somos partidários da concepção 
gramsciana, que percebe o homem como uma formação histórica e que renunciar sua formação "significa permitir que sua personalidade se desenvolva absorvendo caoticamente do ambiente todos os estímulos da vida" (GRAMSCI apud NOSELLA, 2004, p. 12).

O desenvolvimento dos meninos nas instituições criadas pela Sociedade Pestalozzi, principalmente a Fazenda do Rosário, significou a absorção de uma formação limitada - no trabalho manual agrícola e doméstico - e não havia espaço para o amadurecimento de sua personalidade para a escolha da profissão num momento posterior, uma vez que desde os 7 anos de idade já desempenhavam suas funções. Partia-se do pressuposto de que cada criança possui dons inatos, acreditava-se que naturalmente cada uma "descobriria" sua profissão, lembramos que dentro de um limitado rol de possibilidades.

Nem a Escola Tradicional, nem a Escola Nova, nem mesmo uma escola de princípios educativos marxianos, preferíamos ver os meninos das instituições antipoffianas na Escola Única proposta por Gramsci, onde não haveria "inventores" e "descobridores", mas alunos que tomariam posse de um método de investigação e de conhecimento que os levariam "a um certo grau de maturidade e capacidade, à criação intelectual e prática e a uma certa autonomia na orientação e na iniciativa", para aí sim, poderem escolher a sua formação profissional, "formando-se entrementes como pessoa capaz de pensar, de estudar, de dirigir ou de controlar quem dirige" (GRAMSCI, 1978, p. 121).

\section{Considerações Finais}

Nesse trabalho, acompanhamos a trajetória de Helena Antipoff no ensino da capital mineira nas décadas de 1930 e 1940 e, depois de investigar como se desenhou a atuação da educadora no ensino regular, tivemos condições de compreender as motivações que levaram à criação de instituições para receber aqueles alunos considerados "excepcionais". Para a educadora, era a própria organização do ensino que não atendia às necessidades dessas crianças e por isso a necessidade de instituições específicas para atendê-las. Munidos de rica documentação histórica, fomos levados ao interior das instituições criadas por Helena Antipoff, onde focamos nossa análise nos princípios pedagógicos colocados em prática nessas instituições.

Adotamos, como referencial teórico, o Materialismo Histórico, na leitura dos Basaglia (1977), que discutem, numa perspectiva gramsciana, a função dos intelectuais e das instituições. Cientes da crise de paradigmas que assola as ciências de um modo geral, temos dimensão das críticas que incidem sobre essa perspectiva de análise. Perante esse quadro, fomos extremamente rigorosos com a pesquisa documental e privilegiamos os documentos, que nos trouxeram a dinâmica da organização educacional das instituições, com as principais ações empreendidas pelos educadores. Procuramos, com o apoio das citações que apresentam a adoção do trabalho como princípio educativo e a forma como esse princípio foi colocado em prática, demonstrar o caráter unilateral da abordagem institucional. Buscando aprofundar essa análise da relação entre trabalho e educação, recorremos, mais uma vez, ao Materialismo Histórico, em que a noção de trabalho é tomada dialeticamente: identifica o trabalho com a essência humana, pois a primeira ação histórica do homem foi a produção da própria vida material, portanto, sem o trabalho a vida não subsistiria; entretanto, partindo da realidade do sistema capitalista, destaca a forma alienante da exploração do trabalho. Tomando esses pressupostos, observamos categorias que apresentam as possibilidades da união entre ensino e trabalho: trata-se da distinção entre o ensino politécnico e o ensino tecnológico, que nos permitiram proceder à análise da prática nas instituições e apresentar os limites dessa ação educativa, sempre amparados pelas fontes documentais. 


\section{Referências Bibliográficas}

ANDRADA, V. Diário da Fazenda do Rosário. In: ANTIPOFF, H. A Fazenda do Rosário através dos registros. Ibirité: Centro de Documentação da Fundação Helena Antipoff. Boletim da Sociedade Pestalozzi do Brasil, Rio de Janeiro, 1953. Datilografado.

ANTIPOFF, Daniel. Helena Antipoff. Sua vida, sua obra. Rio de Janeiro: J. Olympio, 1975.

ANTIPOFF, H. A Fazenda do Rosário através dos Registros. In: ANTIPOFF, H. 'Histórico' da Fazenda do Rosário. Ibirité: Centro de Documentação da Fundação Helena Antipoff. Boletim da Sociedade Pestalozzi do Brasil, Rio de Janeiro, 1953. Datilografado.

ANTIPOFF, H. A Experimentação Natural: Método Psicológico de Lazursky. In: CDPH (Org.). Coletânea de obras escritas de Helena Antipoff - Psicologia Experimental. Belo Horizonte: Imprensa Oficial de Minas, 1927 - 1992a. 1v.

ANTIPOFF, H. Ideais e Interesses das Crianças de Belo Horizonte. In: CDPH (Org.). Coletânea de obras escritas de Helena Antipoff - Fundamentos da Educação. Belo Horizonte: Imprensa Oficial de Minas, 1930 - 1992b. 2v.

ANTIPOFF, H. Psicologia Experimental - Década de 1930. In: CDPH (Org.). Coletânea de obras escritas de Helena Antipoff - Psicologia Experimental. Belo Horizonte: Imprensa Oficial de Minas, 1930- 1992c. 1v.

ANTIPOFF, H. O Desenvolvimento Mental das Crianças de Belo Horizonte. In: CDPH (Org.). Coletânea de obras escritas de Helena Antipoff - Psicologia Experimental. Belo Horizonte: Imprensa Oficial de Minas, 1931- 1992d. 1v.

ANTIPOFF, H. Amparo ao Pequeno Jornaleiro. In: CDPH (Org.). Coletânea de obras escritas de Helena Antipoff - Fundamentos da Educação. Belo Horizonte: Imprensa Oficial de Minas, 1932 - 1992e. 2v.

ANTIPOFF, H. Escotismo: Perspectivas. In: CDPH (Org.). Coletânea de obras escritas de Helena Antipoff - Fundamentos da Educação. Belo Horizonte: Imprensa Oficial de Minas, 1932 -1992f. 2v.

ANTIPOFF, H. A Formação Física, Intelectual e Moral das Crianças ao Saírem da Escola Pública Primária de Belo Horizonte. In: CDPH (Org.). Coletânea de obras escritas de Helena Antipoff - Fundamentos da Educação. Belo Horizonte: Imprensa Oficial de Minas, 1932 - 1992g. 2v.

ANTIPOFF, H. Preparo da Criança para sua Futura Profissão. In: CDPH (Org.). Coletânea de obras escritas de Helena Antipoff - Fundamentos da Educação. Belo Horizonte: Imprensa Oficial de Minas, 1932 - 1992h. 2v.

ANTIPOFF, H. Da Ortopedia Mental. In: CDPH (Org.). Coletânea de obras escritas de Helena Antipoff - Educação do Excepcional. Belo Horizonte: Imprensa Oficial de Minas, $1934-1992$ i. 3v. 
ANTIPOFF, H. Ortopedia Mental nas Classes Especiais. In: CDPH (Org.). Coletânea de obras escritas de Helena Antipoff - Educação do Excepcional. Belo Horizonte: Imprensa Oficial de Minas, $1934-1992$ j. 3v.

ANTIPOFF, H. Plano para Organização das Classes do $1^{\circ}$ Ano. In: CDPH (Org.). Coletânea de obras escritas de Helena Antipoff - Educação do Excepcional. Belo Horizonte: Imprensa Oficial de Minas, 1934 - 1992k. 3v.

ANTIPOFF, H. O Papel Educativo e Social das Classes Especiais. In: CDPH (Org.). Coletânea de obras escritas de Helena Antipoff - Educação do Excepcional. Belo Horizonte: Imprensa Oficial de Minas, 1934 - 19921. 3v.

ANTIPOFF, H. Assistência aos Menores Desamparados Trabalhadores de Rua. In: CDPH (Org.). Coletânea de obras escritas de Helena Antipoff - Fundamentos da Educação. Belo Horizonte: Imprensa Oficial de Minas, 1934 - 1992m. 2v.

ANTIPOFF, H. Relatório Anual do Instituo Pestalozzi. In: CDPH (Org.). Coletânea de obras escritas de Helena Antipoff - Fundamentos da Educação. Belo Horizonte: Imprensa Oficial de Minas, 1938 - 1992n. 2v.

ANTIPOFF, H. A Função Social da Assistência às Crianças Excepcionais. In: CDPH (Org.). Coletânea de obras escritas de Helena Antipoff - Educação do Excepcional. Belo Horizonte: Imprensa Oficial de Minas, 1946 - 1992o. 3v.

ANTIPOFF, H. Inquérito Sobre o Sentimento Materno nas Meninas de 9 a 17 Anos, Promovido pela Seção de Cooperação da Família da Associação Brasileira de Educação. In: CDPH (Org.). Coletânea de Obras Escritas de Helena Antipoff - Psicologia Experimental. Belo Horizonte: Imprensa Oficial de Minas, 1948 - 1992p. 1v.

ANTIPOFF, H. Sociedade Pestalozzi de Minas Gerais: 1932 - 1962 - Notas por Helena Antipoff In: CDPH (Org.). Coletânea de obras escritas de Helena Antipoff - Educação do Excepcional. Belo Horizonte: Imprensa Oficial de Minas, 1963 - 1992q. 3v.

ANTIPOFF, H. De Lustro em Lustro: os Jubileus das Três Instituições para Excepcionais Instituto Pestalozzi de Belo Horizonte, Fazenda do Rosário Ibirité, Sociedade Pestalozzi do Brasil do Rio de Janeiro. In: CDPH (Org.). Coletânea de obras escritas de Helena Antipoff - Educação do Excepcional. Belo Horizonte: Imprensa Oficial de Minas, 1965 1992r. 3v.

ANTIPOFF, H. A Fazenda do Rosário - Sua Experiência - sua Filosofia. In: CDPH (Org.). Coletânea de obras escritas de Helena Antipoff - Educação Rural. Belo Horizonte: Imprensa Oficial de Minas, 1966 - 1992s. 4v.

ANTIPOFF, H.; BARBOSA, Y. Material para Estudo da Experimentação Natural no trabalho - década de 1940: Escola Rural D. Silvério - Outubro de 1943 - Como Método de Experimentação. In: CDPH (Org.). Coletânea de obras escritas de Helena Antipoff Educação do Excepcional. Belo Horizonte: Imprensa Oficial de Minas, 1943 - 1992. 3v. 
ANTIPOFF, H.; OTTONI, F.; DUARTE, C. Experimentação Natural como Método para Estudo da Personalidade e da Educação do Caráter. In: Revista Brasileira de Saúde Mental. Rio de Janeiro: Universidade do Brasil, 1958. 4v.

BABOSA, Y. Diário da Fazenda do Rosário. In: ANTIPOFF, H. A Fazenda do Rosário através dos registros. Ibirité: Centro de Documentação da Fundação Helena Antipoff. Boletim da Sociedade Pestalozzi do Brasil, Rio de Janeiro, 1953. Datilografado.

BARBOSA, Y. Notas sobre Alunos Internos na Escola Rural D. Silvério, na Fazenda do Rosário. In: ANTIPOFF, H. 'Histórico' da Fazenda do Rosário. Ibirité: Centro de Documentação da Fundação Helena Antipoff. Boletim da Sociedade Pestalozzi do Brasil, Rio de Janeiro, 1953. Datilografado.

BASAGLIA, F.; BASAGLIA, F. O. Los crimenes de la paz: investigación sobre los intelectuales y los tecnicos como servidores de la opresion. México: Siglo XXI, 1977.

CAMPOS, R. H. F. (Org). Helena Antipoff e a psicologia no Brasil. Belo Horizonte: Autêntica, 2002.

CLAPARÈDE, E. A escola sob medida e estudos complementares sobre Claparède e sua doutrina, por Jean Piaget, Louis Meylan e Pierre Bovet. Rio de Janeiro: Fundo de Cultura, 1953.

FARIA FILHO, L. de; VEIGA, C. G. Infância no sótão. Belo Horizonte: Autêntica, 1999.

GRAMSCI, A. Os intelectuais e a organização da cultura. Rio de Janeiro: Civilização Brasileira, 1978.

MANACORDA, M. A. Marx e a pedagogia moderna. Tradução de Newton Ramos de Oliveira; revisão técnica de Paolo Nosella; prefácio de Demerval Saviane - São Paulo: Cortez; Campinas: Autores Associados, 1991.

MARX, K.; ENGELS, F. A ideologia alemã e outros escritos. Selecionados por Otavio Ianni. Trad. Valtensir Dutra e Florestan Fernandes. Rio de Janeiro: Zahar, 1965.

MELO, A. B. Diário da Fazenda do Rosário. In: ANTIPOFF, H. A Fazenda do Rosário através dos registros. Ibirité: Centro de Documentação da Fundação Helena Antipoff. Boletim da Sociedade Pestalozzi do Brasil, Rio de Janeiro, 1953. Datilografado.

NOSELLA, P. A escola de Gramsci. 3ª ed. São Paulo: Cortez, 2004.

PEIXOTO, A. C. A reforma educacional Francisco Campos: Minas Gerais - governo Presidente Antônio Carlos. 1981. Dissertação (Mestrado em Educação). Faculdade de Educação, Universidade Federal de Minas Gerais, Belo Horizonte, 1981.

SOCIEDADE PESTALOZZI Estatutos. Ibirité: Centro de Documentação da Fundação Helena Antipoff, 1939. Datilografado. 


\begin{abstract}
${ }^{1}$ Este trabalho dialoga com dados advindos da pesquisa que integrou a Dissertação de Mestrado intitulada "Helena Antipoff e o Ensino na Capital Mineira: a Fazenda do Rosário e a Educação pelo Trabalho dos Meninos 'Excepcionais' de 1940 a 1948”, defendida no Programa de Pós-Graduação em Educação, da Universidade Federal de São Carlos (UFSCar), por Heulalia Charalo Rafante, sob orientação da Profa. Dra.
\end{abstract} Roseli Esquerdo Lopes, com o apoio da CAPES, em setembro de 2006.

${ }^{2}$ Historiadora pela Universidade Federal de Ouro Preto, Mestre em Educação pela UFSCar, Doutoranda em Educação pela UFSCar. Integrante do Grupo de Pesquisa Terapia Ocupacional e Educação no Campo Social - CNPq e do Núcleo UFSCar do HISTEDBR. Bolsista CNPq.

${ }^{3}$ Terapeuta Ocupacional pela Universidade de São Paulo (USP), Especialista em Saúde Pública pela USP, Mestre em Educação pela UFSCar e Doutora em Educação pela Universidade Estadual de Campinas. Professora Associada do Departamento de Terapia Ocupacional e do Programa de Pós-Graduação em Educação da UFSCar. Integrante do Núcleo UFSCar do HISTEDBR. Coordenadora do Grupo de Pesquisa Terapia Ocupacional e Educação no Campo Social - CNPq. Pesquisadora CNPq.

${ }^{4}$ Segundo Helena Antipoff, "o termo excepcional é interpretado de maneira a incluir crianças e adolescentes que se desviam acentuadamente para cima ou para baixo da norma de seu grupo em relação a uma ou várias características mentais, físicas ou sociais, ou quaisquer dessas de forma a criar um problema essencial com referência à sua educação, desenvolvimento e ajustamento ao meio social" (ANTIPOFF, 1992q, p. 271). De acordo com a referência de análise, havia subcategorias: "excepcionais orgânicos", quando o parâmetro era a característica física ou mental; "excepcionais sociais", quando os meninos eram classificados por sua conduta ou seu caráter, incluindo os meninos abandonados pela família ou pelo responsável. O termo excepcional aparece entre aspas por se tratar de um conceito específico, relacionado a um determinado período histórico. Formulado por Helena Antipoff, esse conceito se cristalizou na história da educação, sendo adotado por especialistas na área de Educação Especial, mas, quando saímos da teoria e partimos para a existência material daqueles alunos considerados "excepcionais", percebemos o viés ideológico na seleção daqueles que recebiam essa denominação.

${ }^{5}$ O Pavilhão de Natal foi proposto por Helena Antipoff, pela primeira vez, em 1932, numa palestra proferida em Belo Horizonte, em que a educadora destacou a situação das crianças trabalhadoras das ruas da capital mineira e chamou a atenção para a necessidade de uma instituição para acolhê-las, apresentando as características dessa instituição. A educadora fez referência ao lançamento da pedra fundamental para a construção desse estabelecimento, ocorrido em dezembro daquele ano e, por isso, a denominação Pavilhão de Natal. Em 1934, Helena Antipoff proferiu outra palestra e voltou a discutir a temática, chamando a atenção, mais uma vez, para a necessidade de uma instituição para atender às crianças trabalhadoras da rua. Além desses documentos, não localizamos outras fontes que indicassem a criação dessa instituição, mas, ainda assim, destacamos essa proposta neste artigo, pois, nos documentos encontrados, a organização do Pavilhão de Natal foi detalhadamente apresentada, constituindo-se em importante referência para a compreensão da proposta de atuação da educadora Helena Antipoff para o atendimento da criança "excepcional social". Quanto ao Instituto Pestalozzi e à Fazenda do Rosário, encontramos ampla documentação a respeito de suas atividades, as quais se tornaram referência na educação dos "excepcionais".

${ }^{6}$ A proposta da "Escola sob Medida" foi desenvolvida por Edouard Claparède e previa que a educação deveria ter como centro dos programas e dos métodos escolares a criança, considerando as aptidões individuais no encaminhamento das práticas pedagógicas (CLAPARÈDE, 1953).

7 A "Experimentação Natural" foi desenvolvida pelo psicólogo russo Alexandre Lazurski, a partir da observação dos alunos em suas atividades escolares. Era necessário observar e escolher comportamentos do indivíduo com base em atividades reais e, a cada reação típica, atribuir uma significação caracterológica que, segundo a intensidade da manifestação, avaliava o grau da reação psicológica. Além de estudar o indivíduo em situações reais, o método podia ser aplicado em qualquer ambiente (ANTIPOFF et al., 1958). Helena Antipoff escreveu um artigo específico sobre essa temática, descrevendo como o psicólogo Alexandre Lazurski chegou à formatação do método (ANTIPOFF, 1992a).

$8 \mathrm{Na}$ concepção de Helena Antipoff, as crianças em "perigo moral" eram aquelas consideradas indisciplinadas, desequilibradas, que apresentam perturbações de caráter e as anti-sociais (ANTIPOFF, 1992h).

${ }^{9}$ Conforme nota 4.

${ }^{10}$ A Escola de Aperfeiçoamento foi criada pelo governo mineiro no contexto da Reforma de Ensino (1927) com o intuito de formar os professores a partir dos princípios da Escola Ativa, preconizados pela Reforma. 
${ }^{11}$ Com ênfase na hereditariedade e no determinismo biológico, os eugenistas preconizavam métodos que buscavam a melhoria do patrimônio genético de determinados organismos vivos. Mas esse conceito não se restringiu ao campo da biologia, estendendo-se ao campo social e político e muitos eugenistas vão buscar, na educação, formas para ajustar o diferente à sociedade (FARIA FILHO e GREIVE, 1999, p. 35-36).

12 “1) varrer os passeios (cimentados); 2) varrer o pátio (terra); 3) limpeza do galpão e sarjetas; 4) limpeza das varandas laterais e da frente dos prédios; 5) limpeza das sanitárias, pias e varanda anexa; 6) limpeza de pó dos móveis; 7) vasculhar a casa; 8) enceração" (ANTIPOFF et al., 1958, p. 22).

${ }^{13}$ As idades variavam de 4 a 18 anos (5 tinham entre 4 e 6 anos; 68 contavam de 7 a 12 anos; 39 estavam com idade entre 13 e 18 anos; 8 tinham a idade desconhecida; 1 tinha mais de 18 anos) (BARBOSA, 1953).

${ }^{14}$ Os diários indicaram outros tipos de atividades: fabricação de goiabada e de requeijão, ordenha da vaca, plantio de pomar, fabricação de rapadura e de doces, capina, moagem de cana, colheita de batatas, aragem de terra por tração animal, plantio de feijão, milho e mandioca.

Artigo recebido em: 13/03/2009

Aprovado para publicação em: 15/05/2009 